\title{
REPENSAR EL HEDONISMO: DE LA \\ FELICIDAD EN EPICURO A LA SOCIEDAD \\ HIPERCONSUMISTA DE LIPOVETSKY
}

\section{RE-THINKING HEDONISM: AN APPROACH \\ TO EPICURUS' CONCEPTION OF HAPPINESS \\ FROM THE POINT OF VIEW OF HYPER- CONSUMER SOCIETY}

\author{
Ramón Román Alcalá - María del Mar Montero Ariza ${ }^{1}$ \\ Universidad de Córdoba
}

Resumen: La búsqueda de la felicidad ha constituido una de las principales preocupaciones del ser humano, y aún hoy esta tarea sigue siendo relevante, pues forma parte de la esencia que nos constituye. Qué sea eso que define dicha felicidad es una cuestión que ha ido variando en el tiempo. La época helenística asumió la tarea filosófica de la búsqueda de la felicidad asociándola a conceptos relacionados con la prudencia, la mesura o la serenidad del alma. En este artículo nos proponemos reflexionar acerca de la noción de felicidad con la que operamos en nuestra sociedad contemporánea; una contemporaneidad definida por la explosión del consumo, la defensa del individualismo y un acuciado progreso tecnológico que hacen que la satisfacción de los placeres sensoriales se asemeje a la auténtica felicidad. Pero ¿proporciona este hedonismo consumista el bienestar completo? De no ser así, ¿es posible la recuperación de un hedonismo responsable que pueda conciliar el consumo con una ética de la felicidad más completa?

Palabras Clave: Epicuro, Lipovetsky, felicidad, bienestar, hedonismo, consumo, individualismo.

Aвstract: The pursuit of happiness has always constituted one of human beings' main concerns, and even today this task is relevant, as it is part of the essence that constitutes us. What it is that defines happiness has changed over time. The Hellenistic epoch took on the philosophic task of the pursuit of happiness, linking it to concepts related to prudence, moderation or serenity of the soul. In this paper we propose to think over the notion of happiness with which we work in our contemporary society; a contemporaneity defined by the ${ }^{1}$ explosion of consumerism, the defense of individua-

1 Fs1roalr@uco.es 
lism and a driven technological progress that put sensory pleasure satisfaction in the place of true happiness. But does this hedonism provide complete well-being? If not, is the re-establishment of a responsible hedonism that could reconcile consumerism with a more complete ethic of happiness possible?

KeYwords: Epicurus, Lipovetsky, happiness, well-being, hedonism, consumption, individualism.

\section{Introducción}

Aunque pueda no ser lo más importante de la vida, siempre se vuelve y se insiste sobre la felicidad, y, a veces de manera obsesiva, dedicamos muchos momentos de reflexión a esta cuestión, y ello a pesar de que no todo el mundo quiere ser feliz de la misma manera. Ya el viejo Séneca decía: «Vivir felices, Galión, todos lo quieren, pero andan a ciegas tratando de averiguar qué es lo que hace feliz una vida $»^{2}$. Esta cita del comienzo de la obra de Séneca «Sobre la felicidad», da idea de que su búsqueda ha constituido una de las principales preocupaciones e inquietudes del ser humano. Pero esta tarea no es fácil, la felicidad no es más que una palabra insignificante a la que se dan significados decisivos. Desde la filosofía se ha pretendido dar respuesta a la cuestión de la felicidad, aunque no todos los periodos históricos han priorizado esta cuestión; en algunos, los seres humanos estaban más preocupados por sobrevivir que por buscar la felicidad, y en otros por el sentido de la vida.

Fue con Aristóteles cuando se dio el inicio de una ética que situaba como fin "último", como bien supremo, como télos al que tienden los seres humanos, la eudaimonia, que se suele traducir por bienestar o felicidad. Para muchos griegos la felicidad tenía que ver con el sentido de la vida, y por ello era un fin en sí misma que había que perseguir. Para Aristóteles esta idea de vida feliz podía expresarse en cuatro formas: la que se basa en el placer, en la riqueza, en la virtud, y la

\footnotetext{
2 Séneca, De vita beata, 1. 1. La filosofía cumple un papel fundamental en esto. Los beneficios de la educación filosófica no son sólo para el filósofo, todo el mundo debe ser depositario de ese beneficio, Séneca lo advierte finamente cuando dice: «Nadie puede llevar una vida feliz, ni siquiera soportable, sin la aplicación a la sabiduría», Epist. 16, 1; esta dedicación a la filosofía es independiente de su estatus social, sea esclavo o libre, varón o mujer. Musonio Rufo no duda en concluir que cualquiera que tenga en orden los cinco sentidos, es decir los tenga y le añada la capacidad de razonar y la responsabilidad moral puede y debe estudiar filosofía.
} 
que considera la vida contemplativa. La felicidad, para él, sólo podía identificarse con la "vida buena», que no será más que actuar conforme a la función propia del hombre. El placer o la riqueza no podían ser portadores de la felicidad, pues eran efímeros y fugaces, y generalmente estaban condicionados por circunstancias externas. La felicidad va unida al desarrollo de las potencialidades del alma: es decir, el cultivo de las virtudes morales (justicia, valentía, templanza, etc.) y las dianoéticas o intelectuales, encontrando la felicidad suprema en la vida contemplativa, propia del sabio.

Este ideal de felicidad cambiará con la llegada del helenismo y la instauración del epicureísmo como escuela filosófica que convierte el placer y el dolor en condiciones epistemológicas de verdad. La filosofía helenística adquiere un matiz esencialmente terapéutico, hasta el punto de que la propia actividad filosófica será percibida como una tarea médica, de forma que, si el médico se ocupa de curar las enfermedades del cuerpo, será tarea del filósofo curar las desolaciones del alma ${ }^{3}$. Y este giro no será característico sólo del epicureísmo. Escepticismo, estoicismo y hasta el cinismo se centrarán en la búsqueda de la felicidad, como reto de una filosofía práctica o ética.

En concreto, el epicureísmo proclama la felicidad para todos los individuos, sin distinción alguna. Así, todas las virtudes tradicionales (templanza, valor o energía del alma, prudencia) encuentran, pues, su lugar en la concepción epicúrea de la conducta individual. Sin embargo, ninguna de ellas tendría valor sino con relación al placer; placer y dolor son afecciones o sentimientos básicos, criterios inmediatos de la percepción sensible. La ausencia del placer reclama ser colmada, provoca naturalmente una apetencia, un deseo. Sin embargo, no todos los deseos deben ser satisfechos con la misma intensidad. El epicureísmo no perseguía el placer desenfrenado y frenético, sino aquél que surge de la eliminación del dolor, la serenidad del ánimo y la dicha interior constante ${ }^{4}$. Por

3 Cf. Crisipo, S.V.F., 3, 471, aquí compara la medicina que cura el cuerpo con la filosofía que cura el alma enferma, y afirma que no es verdad que la segunda sea inferior a la primera. Cicerón, Disp. Tusc., 3, 6 también insiste en que hay un arte médico para el alma que es la filosofía y cuya ayuda no viene de fuera y es ajena a nosotros, sino desde dentro de nosotros mismos; y Séneca en sus $E p .8,2$ escribe que pone por escrito argumentos prácticos y prescripciones que sirven como medicamentos.

${ }^{4}$ Cf. D.L., X, 128-129. García Gual afina este análisis, caracterizando a esta sabiduría como solución que «en medio de una época caótica y de una sociedad enfermiza y decadente, ofrece al hombre con el mínimo de recursos, las mayores posibilidades de ser el artífice de su propia felicidad», cf. Gual, C. y Acosta, E., Epicuro. Ética. La génesis de una moral utilitaria, p. 263. 
consiguiente, la misión de la ética epicúrea debe consistir en el logro de un nuevo tipo de individuo, capaz de conseguir su liberación mediante la eliminación del miedo a la muerte y a los dioses y la superación de la turbación que impide cualquier sentimiento puro y la felicidad. Debe ser suprimido todo temor, toda inseguridad, toda angustiosa insatisfacción, para poder vivir una vida igual a la de los dioses, en divina tranquilidad (ataraxía). Epicuro, que establece el hedonismo como modelo de vida, y la búsqueda del placer como el télos del individuo, es un autor especialmente relevante en un momento como el nuestro, en el que se ha producido, en las últimas décadas, un resurgimiento de la idea hedonista del placer individual. Este modo de entender la felicidad, en nuestros días, se asocia al establecimiento de una nueva forma de temporalidad en la que el presente prima por encima del pasado o el futuro. Al mismo tiempo se ha producido un auge del individualismo que ha sido posible gracias al desarrollo de una cultura de consumo que focaliza sus esfuerzos en ofrecer un amplio abanico de posibilidades y de elecciones de vida, primando la individualidad, el confort, el placer y el disfrute personal. De este modo, la idea de bienestar y de felicidad con la que funcionamos estaría asociada a la explosión de un mundo hiperconsumista, que ha vinculado la idea de bienestar con el acceso a los bienes materiales, de forma que los propios objetos han cambiado su valor funcional por su valor simbólico y estético ${ }^{5}$.

Lo que nos proponemos es reflexionar acerca de qué tipo de felicidad sería esa que se vincula al consumo, y cómo una nueva concepción del hedonismo está presente en la era del individualismo actual. Es preciso descifrar en qué medida ese hedonismo se aleja o se acerca al defendido por Epicuro y cómo una reactualización del hedonismo griego, que al fin y al cabo no estaba tan alejado de ciertas virtudes cívicas relacionadas con la prudencia o la mesura, podría ser la base de un hedonismo responsable que respete el principio natural de la búsqueda del placer sin caer en un sensualismo y egoísmo materialista exacerbado no deseable ${ }^{6}$.

${ }^{5}$ Cf. Featherstone, M., Cultura de consumo y postmodernismo, Buenos Aires, Amorrortu, 1991, p. 121.

${ }^{6}$ Algunos ensayistas contemporáneos como Lipovetsky ya han diagnosticado este tipo de felicidad como felicidad paradójica, pues la sociedad actual se caracterizaría precisamente porque en ella no dejan de darse ciertas contradicciones: especialmente aquella que muestra la liberación del individuo del yugo de la tradición y su apertura a la elección de múltiples estilos de vida gracias a la instauración del consumo, frente a la urgente necesidad de atender a la sensación de infelicidad e inseguridad que produce la falta de referentes que guíen la propia vida. 


\section{Epicuro: la filosofía como búsqueda de la felicidad}

Tras la muerte de Aristóteles, la filosofía, obligada a conducir sus reflexiones por el ámbito de la ética, se convirtió en un arte de vivir. La búsqueda de conocimiento científico-teórico dejó de ser la señal de definición del filósofo, y la filosofía de un hombre se convirtió en «algo» por él vivido. De ahí que la tarea del filósofo se transformara en descubrir la mejor vida, enseñarla, y vivir de ello. La ética, o mejor la filosofía práctica, emergió como la parte rectora del individuo o sujeto. Las conquistas de Alejandro generaron nuevas circunstancias políticas y sociales, que trajeron consigo grandes transformaciones culturales. El concepto de polis tradicional desapareció y se formaron las grandes monarquías, al mismo tiempo que Grecia quedaba reducida a una provincia dentro de un vasto imperio. El sentido de pertenencia a la metrópoli, tan característico de las ciudades griegas, también se vio reducido, y conforme aumentaban las conquistas, el sentido cosmopolita de la política iba desapareciendo ${ }^{7}$.

Aunque en Atenas continuaban funcionando la Academia de Platón (con un sesgo escéptico) y el Liceo de Aristóteles, surgieron dos nuevos centros filosóficos que permitirían el desarrollo del estoicismo y del epicureísmo. Epicuro fundó su propia escuela, conocida como el Jardín, y se constituyó como un lugar espiritual claramente separado de los ideales políticos e intelectuales de la Atenas de Platón y Aristóteles. A diferencia de la Academia de Platón, éste no era un lugar intelectual o de búsqueda de la sabiduría, pues, como explica Mas, a los helenistas no les interesaba la sophía, sino la phrónesis que les permitiera resolver el problema de la vida ${ }^{8}$. La utilidad práctica de la filosofía terminó por determinar por completo la acción del filósofo. La ética afloró al primer plano del interés por la necesidad de buscar la «vida buena» y la metafísica descendió al último. Más considerablemente, la ciencia se divorció de la filosofía y se orientó hacia la búsqueda de profesionales que además de filósofos ejercieran una actividad, principalmente la medicina. La dislocación geográfica confirmó este divorcio: Atenas permaneció siendo el centro principal de filosofía, pero

\footnotetext{
7 Es verdad que Alejandro ayudó a socavar las raíces políticas griegas que todavía estaban presentes en Aristóteles, maestro de Alejandro, pero este último también conoció a Diógenes el cínico, que tuvo que ejercer gran influencia en él, de ser cierto lo que cuenta Diógenes Laercio IV, 32 que dijo: «De no ser Alejandro me habría gustado ser Diógenes»; y el cínico también iniciaba ya su particular cruzada contra los valores básicos y tradicionales de la sociedad griega.

${ }^{8}$ Mas Torres, S., Historia de la Filosofía Antigua. Grecia y el helenismo, Madrid, UNED, 2003, p. 192.
} 
la ciencia emigró a Egipto, a Alejandría, buscando las subvenciones financieras de los Ptolomeos.

En esta tesitura, los epicúreos se preocuparon de tres partes esenciales de la filosofía: la física, la ética, y el estudio del criterio o del canon ${ }^{9}$, que aunque era un modo de introducir la lógica, lo consideraron parte de la física. Para los epicúreos, las explicaciones de la ciencia no interesan más que en el modo en que son útiles para alcanzar la tranquilidad del alma.

Por ello, y de este modo entramos ya en el terreno que nos interesa, la ética de Epicuro es hedonista, y por hedonismo, entendemos: «que el placer es el comienzo, fundamento, culminación y término de una vida feliz, que la consecución del placer y la evitación de su contrario, el dolor, guía elecciones y rechazos, que no hay otro objetivo trascendente, el placer es el prôton agathón, el sumun bonum de los latinos, y que la propia naturaleza de los seres animados fija ese criterio básico de conducta» ${ }^{10}$.

Los principios de Epicuro son sencillos y claros: el ser humano tiene la necesidad de una sola cosa, ausencia de dolor en el cuerpo, presencia del placer en el alma. Si los obtenemos, alcanzaremos la felicidad como hombres sabios; mientras que su falta nos hundirá en la miseria del hombre necio. El ideal del sabio persigue, pues, un conocimiento que se centra en la serenidad del placer individual, y no en la perfección colectiva de las relaciones humanas, que difícilmente pueden ser logradas en convivencia con los demás. Dicho sin rodeos, la filosofía epicúrea intenta lograr la salud individual de cada hombre más que la salvación general de la humanidad, una posición que aflora en casi todas las actitudes éticas de nuestra época. García Gual afina este análisis, caracterizando a esta sabiduría como solución que «en medio de una época caótica y de una sociedad enfermiza y decadente, ofrece al hombre con el mínimo de recursos, las mayores posibilidades de ser el artífice de su propia felicidad» ${ }^{11}$.

9 Cf. D.L., X, 30: «Los epicúreos no distinguen claramente la canónica del resto de partes de la filosofía, más bien la reconocen como un presupuesto básico y necesario para hablar de filosofía, una teoría del conocimiento actual que sirve de base a todo el sistema». Parece más que es el propio Diógenes Laercio quien tiene un interés pertinente en dejar constancia de la estructura tripartita y aclararla.

${ }^{10}$ Cf. Mas Torres, S., Op. Cit., p. 201.

11 García Gual, C. y Acosta, E., Epicuro. Ética. La génesis de una moral utilitaria, Barcelona, Barral Editores, 1973, p. 263. 
Así, todas las virtudes tradicionales (templanza, valor o energía del alma, prudencia) propias de la conducta individual, sólo tienen sentido con relación al placer. La ausencia de placer reclama ser colmada, provoca naturalmente una apetencia, un deseo, pero no todos los deseos deben ser satisfechos con la misma intensidad. El epicureísmo no perseguía el placer desenfrenado y frenético, sino aquél que surge de la eliminación del dolor, la serenidad del ánimo y la dicha interior constante.

Desde este punto de vista, el placer sería el comienzo, el fundamento y la culminación del vivir feliz. Esta tajante afirmación hace que algunos comentarios hayan considerado a Epicuro como un extremado hedonista que busca el placer por encima de todo. Pero hay que juzgar el placer de los epicúreos en una doble vertiente: un placer en reposo, cuya realización se encuentra en la ataraxia, y un placer en movimiento. El único placer completo es el placer en reposo, pues, como observa Leclerq, «el placer nace de la satisfacción de un deseo y el deseo proviene de un sufrimiento: el deseo nace de que sufro por alguna cosa. Deseo comer cuando tengo hambre, y el hambre es un sufrimiento» ${ }^{12}$.

El placer en movimiento es el placer del sufrimiento que se elimina: de ahí que los epicúreos condenasen una vida de relajación sensual; pensaban que se podía alcanzar mejor placer a largo plazo, desarrollando la calma, la emancipación de las preocupaciones y de la angustia, la ausencia virtual de apetitos físicos, el cultivo de la mente. El término hedoné fue utilizado por Epicuro en cuatro sentidos muy diferentes: significa el placer del cuerpo o bien del espíritu. Y, a la vez puede ser o cinético (producido por un estímulo exterior) o catastemático (originado en sí mismo). Sólo para el placer del cuerpo es válida la traducción por el término castellano placer. Para los demás casos, Farrington propone el término alegría (voluptas, en versión latina) que incluiría desde el placer físico hasta el éxtasis en la contemplación de la divinidad ${ }^{13}$.

Por ello debe imponerse el rechazo de la concepción vulgar vertida en torno al concepto de placer del epicureísmo y reconocer como supremo el placer de la

${ }^{12}$ Leclerq, J., Las grandes líneas de la filosofía moral, Madrid, Biblioteca Hispánica de Filosofía, 1976, p. 85; Cf. Rist, J.M., Epicurus. An Introduction, Cambridge, Cambridge University Press, 1977, pp. 109-111.

13 Farrington, B., La rebelión de Epicuro, Barcelona, Ed. Laia, 1974, p. 179; Cf. Mondolfo, R., La conciencia moral de Homero a Demócrito y Epicuro, Buenos Aires, Editorial Universitaria de Buenos Aires, 1968, pp. 53-54; Vid. García Gual, C. y Acosta, E., Op. Cit., pp. 210-217. 
sobria razón, declarando que no existe gozo alguno al margen de una vida prudente, sabia y justa. El placer, fin supremo de la ética de los epicúreos, consiste en suprimir el dolor por la satisfacción de las necesidades. Todo lo que rebase este fin podrá variar el placer, pero en ningún momento podrá aumentarlo. Por tanto, el verdadero placer es el placer en reposo, un placer tranquilo que se convierte en el ideal de la vida que se halla en la no turbación del espíritu, en una serenidad permanente.

Este placer del espíritu no es ajeno al cuerpo. Los epicúreos son, sin duda, sensualistas, y las actividades más intelectuales se reducen, para ellos, a actos físicos. Si no tuviésemos sentidos y no fuésemos de carne, el placer no podría aparecerse como un bien ${ }^{14}$. El epicúreo tiene, pues, una moralidad bastante elevada: es dueño de sí; razona sus actos, no se deja llevar por los excesos de la carne; desdeńa los placeres groseros. Nietzsche, con esa agudeza que lo caracteriza, recoge esta moderada idea en su obra La gaya ciencia: «Sólo uno que sufría constantemente pudo inventar felicidad semejante, la felicidad de unos ojos ante los que se ha encalmado el mar de la existencia y que ahora ya no se cansan de su superficie (...) nunca antes se presentó una moderación tal de la voluptuosidad $»^{15}$.

¿Es acaso, pues, el epicureísmo un simple revolcarse en la actividad sensual, una destrucción de lo que tradicionalmente ha sido calificado lo más noble y elevado en la vida de los individuos? Evidentemente, no; apenas leamos cualquier estudio crítico y serio debemos coincidir en que tales manifestaciones son, cuanto menos, deshonestas. Como sabemos, el epicureísmo no recomienda la alegría intensa del glotón o del libertino, ni los placeres humanos de la cama o de la mesa, sino la simple autosuficiencia interior, derivada de una mente tranquila y del consuelo del espíritu. No olvidemos, por ejemplo, que Marcuse critica al hedonismo epicúreo el afán por domesticar, controlar y «racionar» el impulso, eliminando la fuerza revolucionaria de esta doctrina. «Se trata — dice Marcuse - de un hedonismo negativo: su principio es más evitar el dolor que procurar el placer. La verdad, según la cual debe ser medido el placer, consiste en evitar el conflicto con el orden existente: lo socialmente permitido, la forma deseada del placer» ${ }^{16}$. Epicuro introduce un elemento que eleva su concepción

${ }_{14}$ Plutarco, Adversus Colotem, 1112a; Cf. Fraisse, S., «Lucréce et Pascal», Esprit, 27 (1959), pp. 437-453.

15 Nietzsche, F., La gaya ciencia, 1, 45, Barcelona, Pequeña Biblioteca Calamvs scriptorivs, 1979.

16 Marcuse, H., "A propósito de la crítica del hedonismo", en Cultura y Sociedad, Buenos Aires, 1967, p. 104. 
ética del hedonismo a un nivel superior que el establecido por los cirenaicos. Epicuro va a dar una importancia especial a la phrónesis, la virtud encargada de calcular los placeres, introduciendo así un elemento racional en su consideración del hedonismo. La phrónesis es la que permite guiar la elección correcta de los placeres, y éstos pueden ser de dos clases: no naturales, que serían los que producen mayores dolores, y naturales, que a su vez se dividen en no necesarios, cuya causa está en la propia naturaleza de los seres animados, y necesarios, que se corresponderían con aquellos relacionados con la conservación de la vida, que requieren una satisfacción inmediata y son fáciles de conseguir. Esta clasificación de los placeres pone de manifiesto un rechazo a los placeres del lujo, aquellos placeres no naturales ni necesarios, y una mayor consideración con los placeres naturales y necesarios como la comida o la bebida no lujosas.

El hedonismo de los cirenaicos fue más radical que el de Epicuro. Éstos defendían la idea de que si hay algo de lo que podemos estar completamente seguros es de la sensación de placer y dolor, convirtiéndolas así en criterios epistemológicos de verdad. El placer y el dolor son diferentes para cada uno (o al menos eso se deriva de las diferentes descripciones que hacemos del placer o el dolor, o de los distintos umbrales de dolor o placer que tienen los seres humanos), lo que es igual para todos es el uso de las palabras "placer» $\mathrm{y}$ «dolor», asociadas a determinadas sensaciones. De este modo, el placer y el dolor subjetivos se convierten en criterio de verdad. El placer se constituye como el télos al que tiende el individuo de forma natural. Según Aristipo de Cirene podemos hallarnos en tres estados: placer, dolor y el estado neutro. Lo positivo es el placer, mientras que la ausencia de dolor no constituye ningún estado, pues sería similar al estado del durmiente. Además el placer es presente y hay que gozarlo aquí y ahora, pues del pasado nada hay que se pueda rescatar ya, y el futuro es incierto, por ello lo único que pertenece al individuo es el presente inmediato ${ }^{17}$. El hedonismo defendido por los cirenaicos constituye una concepción ética del hedonismo extrema, y que en cierto modo comparte algunos rasgos con el hedonismo presente en nuestra contemporaneidad.

17 En un sentido metafórico eso es lo que intenta Epicuro explicar en su famoso pasaje de Diógenes Laercio sobre la inmutabilidad del todo, el eterno presente de la Carta a Herodoto, D.L. IX, 39; Brunschwig estudia ese pasaje y defiende en ese perpetuo presente que «el todo siempre ha sido tal como es ahora, y él será siempre así», Cf. Brunschwig, J., Etudes sur les philosophies hellénistiques, Epicurisme, stoïcisme, scepticisme, París, Presses Universitaires de France, 1995, pp. 15-42, principalmente p. 39; cf. también Mas Torres, S., Op. Cit., p. 202. 
Frente a este hedonismo en cierto modo más desenfrenado, Epicuro defiende, como hemos visto, que el placer supremo se identifica con la ausencia de dolor, al mismo tiempo que establece una diferencia entre dos tipos de placeres: los cinéticos y los catastemáticos. De este modo se eliminan los estados intermedios, pues el estado en el que no hay dolor se corresponde con el máximo placer. Además, el placer es natural y no es ilimitado, como defendían los cirenaicos. También a diferencia de éstos, establece que los placeres del alma son superiores a los del cuerpo, pues los placeres del cuerpo sólo pertenecen al presente. Los dolores más graves serán los del alma, que tarda más en recuperarse que el cuerpo. Los dolores sufridos en el cuerpo son fáciles de eliminar, al mismo tiempo que defiende que la mente tiene un poder mayor para contrarrestar el dolor físico que el dolor del alma. Epicuro, consolida así una ética hedonista más moderada que la de los cirenaicos elevando la importancia de saber elegir bien los placeres, al mismo tiempo que aprender a limitarlos.

\section{La idea de bienestar en la sociedad hipermoderna}

Es de especial relevancia en nuestra época reflexionar acerca del nuevo hedonismo que se instaura con la aparición del consumo de masas, y su transformación en un hedonismo que exige un disfrute de todos los sentidos, con la consolidación de un consumo más personalizado e individualizado. Algunos ensayistas como Lipovetsky, desde una mirada filosófica, han puesto el acento en el hedonismo que se respira en la época actual, mostrando que nos encontramos en una sociedad hipermoderna, que pone el acento en la explosión de los sentidos, en la cultura del goce individual, en la privatización de los placeres asociados a las oportunidades que ofrece el consumo, y que se identifican con la felicidad. En este capítulo intentaremos reflexionar acerca de la noción de bienestar con la que funcionamos, y de qué modo está presente esa concepción del hedonismo consumista, que en cierta medida, nos proporciona la felicidad sólo a medias.

Hemos visto cómo la felicidad está asociada a la búsqueda del placer. Sin embargo, el hedonismo actual se aleja de la tesis defendida por Epicuro y se acerca más a los presupuestos establecidos por los cirenaicos. No cabe duda de que vivimos en la sociedad del placer, y que en nuestros días, está presente una concepción de la felicidad que se aleja de forma paulatina de los ideales tradicionales del sacrificio y el esfuerzo, para centrarse en el auge de estilos de vida vinculados a la satisfacción personal y el goce individual. 
Gilles Lipovetsky se ha referido a la época actual con el adjetivo de sociedad hipermoderna, haciendo alusión a una tercera gran transformación en el ámbito social ${ }^{18}$, cuyas precursoras serían la modernidad y la postmodernidad. La modernidad se constituyó como ese movimiento caracterizado por un auge de la racionalidad, una confianza en la razón absoluta, mientras que la denominada postmodernidad ${ }^{19}$ rompía con esa confianza en los grandes metarrelatos y daba paso al surgimiento de un individuo más autónomo, aunque inspirado todavía en los ideales tradicionales. Desde final del siglo XX nos encontramos en la etapa de la hipermodernidad. Más allá del discurso abierto acerca de la legitimidad de la postmodernidad, y dejando de lado la crítica de sus detractores así como el aplauso de sus seguidores, no es posible negar la existencia de un tipo de sociedad que se caracteriza por los tres rasgos esenciales: el consumo, el individualismo y el progreso tecnológico ${ }^{20}$.

Todos estos cambios sociales tienen dos características comunes que definen la situación: por un lado, la sociedad de mercado, desbocada ante la imposibilidad de ser regulada, o de atenuar la influencia que las instituciones (políticas o religiosas) que la controlan, tienen sobre ella; y por otro, «el principio de individualidad autonómica», máximo exponente del retroceso del Estado en la vida de la sociedad, y su sustitución por la privatización total, hasta de la vida íntima ${ }^{21}$.

En este modelo de sociedad se ha desarrollado un hedonismo que viene determinado por la explosión del consumo ${ }^{22}$. Este hecho se expresa en la mul-

18 Para Lipovetsky, el prefijo «hiper» se ha apoderado de todas las parcelas de nuestra vida, un tiempo de liberación total de la propia modernidad con una economía globalizada y liberal, Les Temps hipermodernes, París, Grasset, 2004, pp. 50-51.

19 Si Rubio Carracedo habla de que es «una indignación moral ante los excesos y desastres provocados por el programa de la modernidad" (Rubio Carracedo, J., Educación Moral, postmodernidad y democracia, Madrid, Ed. Trotta, 1996, p. 109), Turkott advierte que la postmodernidad «solo puede apreciarse como una expresión de la crisis de la modernidad..., una expresión que dramatiza los problemas acarreados por la modernidad inconclusa» (Turkott, L.M., Critica al postmodernismo, Semanario Etcétera, México, jueves 24 de julio 1997), y el propio Lipovetsky dice que a la modernidad «le sucedían horizontes más cortos, una temporalidad dominada por lo precario y lo efímero" (Les Temps hipermodernes, París, Grasset, 2004, p. 49).

20 Cf. Ruíz, J.C., De Guy Debord a Gilles Lipovetsky: el tránsito de la categoría de lo social hacia la categoría de lo individual. Director: Ramón Román Alcalá. Tesis doctoral. Universidad de Córdoba, Departamento de Ciencias Sociales y Humanidades, 2002, pp. 152-153.

21 Carracedo, R., Op. Cit., p. 52.

22 Touraine dice que no podemos definirnos ya como seres sociales, sino como consumidores globales, personas desarraigadas, desnacionalizadas, que ya no se definen con referencias a una colectividad con identificaciones o identidades singulares. La clase, la nación, la educación, etc., 
tiplicidad de espacios destinados a ofrecer una gran cantidad de productos que promueven la individualización, pues el consumo de masas se ha transformado en un consumo personalizado, en el que las marcas se preocupan por ofrecer lo oportuno y particular a cada cliente, con productos a la carta, promoviendo la felicidad privada y el goce de los sentidos aquí y ahora. Un hedonismo de corte consumista, que prioriza el bienestar y los placeres del cuerpo, enfocando sus pretensiones hacia una cultura del ocio, del tiempo libre, y de las vacaciones, y que lucha contra el paso del tiempo, intentando que el presente y la juventud no se escapen. Lipovetsky ${ }^{23}$ ha afirmado en múltiples ocasiones que la cultura actual viene caracterizada por una entrega a los placeres sensoriales y la promoción de un deseo cada vez mayor de gozar del consumo, de la moda y del tiempo libre, como una esfera única que propiciaría una felicidad simbólica, promovida sobre todo por la publicidad, cuyo cometido será mantener la novedad, lo nuevo, de forma que los artículos queden obsoletos en tiempo récord.

Lo que, según Lipovetsky, ha ocurrido es una privatización de los placeres privados del consumo de distracciones, que se identifican con la felicidad: Viajes, turismo, deportes, televisión, cine, salidas con amistades: lo que domina es la propagación y pluralización de placeres elegidos en función de los gustos y aspiraciones de cada cual ${ }^{4}$. Está triunfando una lógica del tiempo individualista, centrada en el consumo dirigido a conquistar los tiempos del ocio, que pone en auge el individualismo, la vuelta del sujeto a sí mismo demandando más tiempo para el disfrute, para hacer lo que le apetezca, para afirmar sus gustos subjetivos. Y esto produce una paradoja, un efecto «malestar» freudiano novedoso, de repente el sujeto se ve en la obligación de informarse, a tomar iniciativas que lo conduzcan a la auto-satisfacción en el consumo, aparece el orgullo de saber consumir, el sentirse orgulloso de la elección realizada, es decir, se encuentra responsabilizado

todo esto se vuelve ahora secundario (Touraine, A., "¿Después del postmodernismo? La modernidad», en AA.VV., Y después del postmodernismo ¿qué?, Barcelona, Anthropos, 1998, p. 20).

${ }^{23}$ El nuevo hombre es un Narciso apoyado y defendido por la sociedad de consumo que dirige sus productos hacia este nuevo individuo que pretende únicamente satisfacerse a sí mismo; Cf. Lipovetsky, G., L’ère du vide, París, Gallimard, 1983, p. 9, 120 y 153; aquí en esta última página llega a decir que «la era del consumo no sólo ha descalificado la ética protestante, ha liquidado el valor de la existencia de las costumbres y tradiciones».

${ }^{24}$ Lipovetsky, G., La felicidad paradójica, ensayo sobre la sociedad de hiperconsumo, Barcelona, Anagrama, 2007, p. 202. 
de todas sus elecciones que le provocan desestabilización personal ${ }^{25}$, acompañada de una desmotivación de los asuntos públicos ${ }^{26}$.

El hedonismo que percibimos es diferente al de hace unas décadas. Hemos pasado de una sociedad que valoraba lo cuantitativo, en la medida en que se exigía una explosión de los placeres desenfrenada y en la que la cantidad de disfrute era importante, a una sociedad (a pesar de la crisis) que valora lo cualitativo, el gusto por lo exquisito, los placeres sensibles, la calidad en el bienestar. Sin embargo se produce una paradoja en esta concepción del hedonismo. En la Modernidad la felicidad se eleva a ideal supremo, y la moral se consolida como ciencia de la felicidad que imagina un mundo distinto. Una época que se caracteriza, sobre todo, por la confianza en el poder de la ciencia y de la técnica para acceder a una sociedad distinta, y en la que se adopta una visión optimista del futuro, pues gracias a las aplicaciones técnicas se podrán eliminar las desdichas del hombre. En esta visión determinista del progreso, siempre está presente la idea de que la historia avanza hacia algo mejor, de forma que el pasado es algo a superar. Se cree en la progresiva trayectoria del hombre hacia la felicidad completa. Lipovetsky llama a este hombre el Homo Felixx ${ }^{27}$. La felicidad se vincula cada vez más al progreso técnico y a la acumulación de bienes, máxime después de la instauración del capitalismo de consumo. A partir de este momento, la idea de la felicidad deja de proyectarse hacia la ensońación de un futuro mejor, y salta de los discursos utópicos, al momento presente, al instante inmediato. La era consumista permite disfrutar de los placeres al momento, aquí y ahora, dejando a un lado el tiempo de la espera.

La novedad de nuestra época no está en que el individuo se preocupe por la búsqueda del placer o de la felicidad, esta ha sido una preocupación que ha existido desde siempre, como ya señalábamos en la introducción, la novedad viene dada porque a partir de la década de los cincuenta la felicidad se identifica con la mejora de la calidad de vida en cuanto a equipamiento material,

25 Existe cierta anomalía hoy en el juicio de realidad que está implícito en toda conducta, para ser más exactos hay hoy confusos enjuiciamientos de la realidad que producen fases cercanas a lo que los psiquiatras denominan «delirios», que no constituyen una creencia errónea, sino un saber erróneo; Cf. Díez Patricio, A., "Creencia y Delirio», Rev. Asoc. Esp. Neuropsiq., marzo 2011, vol. 31, pp. 71-91, principalmente, pp.72-73; Cf. también del mismo autor: «La psicogénesis del delirio en la obra y en la época de E. Kretschmer», Rev. Asoc. Esp. Neuropsiq., Dic. 2001 (80), pp. 73-97.

${ }^{26}$ Cf. Lipovetsky, G., L’ère du vide, París, Gallimard, 1983, p. 159. Por un lado la felicidad paradójica, y por otro, la sociedad de la decepción.

27 Ibid., p. 319. 
sobre todo en el confort, con la incorporación del progreso a la vida cotidiana. Pero esto ha producido un efecto imprevisible: una constante decepción personal ya que el consumo de pronto no está relacionado con la felicidad. El consumo produce satisfacciones inmediatas, instantáneas y completamente reales, pero ese resultado siempre es a corto plazo, y genera frustración, ya que enaltece una faceta del mismo que es la que menos nos gusta. Por ello, esta idea, según Lipovetsky, ha cambiado ${ }^{28}$ una vez más, pues nuestra felicidad hoy no sólo se identifica con un cierto grado de confort y bienestar, que se dan por hechos, sino que procuramos dejar de lado esa visión tecnificada y funcional del progreso, para exigir un confort más individualizado, capaz de procurar sensaciones agradables. Se produce una auténtica exigencia de disfrute a través de los sentidos.

Sin embargo, esa progresión hedonista ilimitada no ha sido suficiente para evitar el pesimismo de su falta de eficacia. Como dice Lipovetsky, lo que se ha disuelto, lo que se ha diluido, es la fe en un futuro mejor y más feliz. El consumo se concibe en función de la mejora de la felicidad de los individuos, y en todos los ámbitos abundan los consejos para que seamos más felices, pero, al mismo tiempo que aumentan las posibilidades de consumo, crece la preocupación por la degradación de los ecosistemas, peligran las energías no renovables; y conforme aumenta el desarrollo tecnológico en el ámbito de las comunicaciones, más aislados y solos nos sentimos, a medida que damos más importancia al dinero, más se prolonga nuestra insatisfacción por no tener todo lo que deseamos, y por si esto fuera poco, las grandes compañías publicitarias, que han pasado de vender productos con significación cultural, a vender emociones, sentimientos y sensibilidades asociadas al bienestar propio, se encargan de generar el deseo constante de consumir, identificando este proceso con el alcance de la felicidad instantánea. En palabras de Lipovetsky:

Indiscutiblemente debemos partir del mundo del consumo. Con la profusión lujuriosa de sus productos, imágenes y servicios, con el hedonismo que induce, con su ambiente eufórico de tentación y proximidad, la sociedad de consumo explicita sin ambages la amplitud de la estrategia de la seducción. Sin embargo ésta no se reduce al espectáculo de la acumulación; más exactamente

${ }^{28}$ Hay un párrafo clarificador al respecto del propio Lipovetsky en Le Bonheur paradoxal, París, Gallimard, 2006, p.14, cuando observa: «La inmensa mayoría se declara feliz, pero la melancolía y el estrés, la depresión y la ansiedad forman un río que aumenta de manera inquietante. Mayoritariamente uno se declara feliz, pensando que los otros no lo son». 
se identifica con la sobremultiplicación de elecciones que la abundancia hace posible con la latitud de los individuos sumergidos en un universo transparente, abierto, que ofrece cada vez más opciones y combinaciones a medida ${ }^{29}$.

Su cometido no es otro que el de despertar el deseo y convertirlo en necesidad, hacernos sońar con todos aquellos artículos que nunca tendremos, y que representan la odisea de la felicidad. La clave para ello la encuentra en la posibilidad de convertir en novedad cualquier objeto, y ante la novedad constante, los viejos artículos van quedando relegados al cajón del olvido, despertando nuevamente los deseos ante lo novedoso. En estas circunstancias siempre se produce la frustración de un deseo constante nunca satisfecho.

La pregunta que debemos hacernos debe estar en relación con la capacidad del sistema consumista de procurarnos la felicidad. La asociación felicidad/consumo se ha convertido en el sistema de referencia para el individuo contemporáneo. No estamos dispuestos a renunciar al lujo o al confort, a los placeres de los sentidos, y quizás no sea conveniente o necesaria esta renuncia. Una visión catastrofista del consumo nos impediría admitir que su dinámica proporciona satisfacciones reales en la medida en que ha aumentado nuestra posibilidad de acceso a múltiples placeres. No sería conveniente defender la idea de que el consumo es negativo en todos sus ámbitos, pues como decimos, esta sociedad del hiperconsumo permite el disfrute cada vez más numeroso y frecuente de diferentes placeres, así como la posibilidad de gozar de libertades y cambios. Sin embargo, el problema surge al confundir el disfrute de las satisfacciones reales que el consumo proporciona, con la auténtica felicidad. La felicidad debería constituirse como algo más que el disfrute material ¿Cómo podríamos conciliar el funcionamiento de esta sociedad de hiperconsumo con el alcance de una felicidad más completa?

\section{La recuperación de la ética epicúrea: una apuesta por un hedonismo responsable}

Quizás la clave para comenzar a pensar en términos de propuestas esté en la siguiente reflexión: el hedonismo epicúreo se identificaba con la paz y la tranquilidad del alma, disfrutando de los placeres, en cierta forma, de un modo racional.

${ }^{29}$ Lipovetsky, G., L'ére du vide, París, Gallimard (colección Folio Essais), 1983 p. 27; La era del vacio, Barcelona, Anagrama, 1986. p. 18. 
En nuestro presente, los placeres son más cada día, y siempre son placeres en movimiento, placeres que hay que prever y que organizar, desarrollando así una civilización exageradamente hedonista que despierta una mayor conciencia de la complejidad de la vida. Hemos desarrollado la denominada cultura preventiva, existe una ansiedad en el ámbito de la salud generalizada, y no conseguimos eliminar las tensiones entre el presente y el futuro, que se presenta incierto. Dice Lipovetsky que la ociosidad despreocupada del hedonismo retrocede a medida que cada cual se convierte en agente autónomo e informado, sustituyendo el consumo inconsecuente por un consumo post-conformista ${ }^{30}$. Hay que paliar parte del efecto satisfactorio que se ha entronizado en el consumo en masa. No nos dice Lipovetsky que tengamos que dejar de consumir, la necesidad del consumo es vital de cara al desarrollo de las sociedades, pero podemos regular y focalizar el consumo como tal, asumiendo que no podemos buscar alternativas al consumo porque la sociedad en la que nos movemos es una sociedad del hiperconsumo.

Epicuro se adelantó a este consumo orgiástico de los placeres, y por eso advertía que los placeres en reposo son los únicos que procuran la felicidad al individuo. Las cosas materiales, por el contrario, son pasajeras y no proporcionan el bienestar (la felicidad). Sólo lo imperecedero puede llevar a cabo esta labor. Se trata de una defensa de la ética que considera que la avaricia, la ambición o la lujuria no proporcionan felicidad, sino que son las causantes de las calamidades del ser humano. Estas cosas son «tan nefastas, que imponen una dictadura a las vidas, dejándolas insatisfechas aun en el colmo del éxito» ${ }^{31}$. La filosofía epicúrea establece que el deseo del hombre por buscar la felicidad en la posesión de los bienes sólo puede ser un reflejo de su inseguridad y de sus miedos. Pero el ser humano debe ser capaz de reducir sus angustias, y esto lo conseguirá eliminando su miedo a la muerte, que es la fuente de todos los temores. Lucrecio, el discípulo de Epicuro, decía que la tranquilidad del alma sólo es posible a través de la ausencia de las necesidades y de la liberación de las angustias. El epicureísmo defiende que la felicidad no podrá ser alcanzada por medio de la riqueza, del poder o de la fama, al contrario, la renuncia a estos bienes es lo que permitirá la salud del alma.

${ }^{30}$ Así la obsesión consumista por la edad, la sanidad y la seguridad no se celebra y la humanidad al final se muestra siempre vulnerable y frágil; Lipovetsky, G., Le Bonheur paradoxal, París, Gallinard, 2006, p. 231. Cf. Scitovsky, T., The joyless economy, New York, Oxford University Press, 1992. Este economista norteamericano ya reflexionaba en 1976 sobre la necesidad de "constante novedad", y sobre la felicidad en su relación con el consumo.

${ }^{31}$ Román, R., Lucrecio: Razón filosófica contra superstición religiosa, Córdoba, UNED, p. 134. 
La felicidad y la dicha no la proporcionan ni la cantidad de riquezas, ni la dignidad de nuestras ocupaciones, ni ciertos cargos y poderes, sino la ausencia de sufrimientos, la mansedumbre de nuestras pasiones y la disposición del alma al delimitar lo que es por naturaleza ${ }^{32}$.

La concepción de este hedonismo ético supone una defensa de virtudes como la templanza o la prudencia, necesarias para la paz interior y la tranquilidad del alma, en la medida en que en relación al placer, permiten discernir la intensidad con la que los deseos deben ser satisfechos. El hedonismo de Epicuro no defiende una concepción del placer desenfrenado y frenético sino que hace uso de las virtudes para conseguir la serenidad del ánimo y la paz interior a través de la eliminación del dolor. Recordemos que la ausencia de dolor constituye el máximo placer. En este sentido, hay una apuesta por la búsqueda del placer a largo plazo. El epicureísmo se constituye, por tanto, como una concepción moral elevada, en la que el placer no puede existir si no es vinculado a una vida justa y prudente. Se trata de funcionar con un concepto de placer distinto que refiere a un hedonismo razonado y razonable ${ }^{33}$.

Ante esta concepción del hedonismo, antigua pero eficaz y razonable, nos encontramos en nuestra época con lo que ya hemos comentado, una concepción de la felicidad asociada a los placeres en movimiento, al goce presente y en ocasiones sin mesura, $\mathrm{y}$ a un rechazo por el cultivo de los placeres a largo plazo, pues se impone la temporalidad del instante, del aquí y ahora. Aunque no debemos olvidar que no sólo consumimos para satisfacer las necesidades básicas, sino que en el consumo, el individuo encuentra una fuente de sueños, de distracciones, de experimentación y aprendizaje, de descubrir nuevos horizontes y de aligerar la existencia cotidiana (el imperio de lo efimero), una especie de espiral de abnegación del placer que obligará, sin duda, a una nueva consideración en la forma de consumir, que se reoriente hacia vías más justas y más igualitarias ${ }^{34}$. En este sentido apuntan ya las campañas de consumo responsable, y el establecimiento de una ética del consumo que tenga en cuenta las consecuencias de un materialismo excesivo. El establecimiento de un hedonismo que no esté dispuesto a renunciar a los placeres de la vida, pero que se sitúe siempre en una actitud responsable con respecto al consumo de esos placeres, podría conciliar nuestra actitud consumista

32 Plutarco, De aud. Poet., 14, 37 A: Usener, frg. 548.

33 Román, R., "El placer y la libertad en Epicuro y Lucrecio», Axerquia, Revista de Estudios Cordobeses, n. ${ }^{o} 8$ (1983), pp. 45-52.

34 Lipovetsky, G., Le Bonheur paradoxal, París, Gallimard, 2006, pp. 140-145. 
con la persecución de un ideal de vida más consciente de los problemas derivados del hiperconsumo, asociados por ejemplo a la degradación de la naturaleza y el agotamiento de los recursos.

Por otro lado, evitar la identificación de la vida feliz con la posesión de bienes y artículos de consumo, permitiría asemejar nuestro ideal de felicidad al desarrollo de virtudes proclamadas por el hedonismo epicúreo, como son la templanza o la prudencia, que permiten situarnos en una concepción de la ética que da la importancia justa a los placeres, pero primando el despliegue de las capacidades que nos hacen verdaderamente humanos y que permiten una felicidad más completa ${ }^{35}$, en la medida en que ésta no se basa en lo efímero y fugaz de los placeres momentáneos, sino en el desarrollo de la vida virtuosa y todo lo que eso conlleva.

Lipovetsky argumenta que la espiral del hiperconsumo estará presente, al menos hasta que dejemos de mantener esa identificación entre felicidad y satisfacción del máximo de necesidades y la renovación sin fin de objetos y diversiones ${ }^{36}$. Para que esto pueda darse deben aparecer nuevas formas de valorar el goce de lo material, debemos transitar nuevos espacios para otro tipo de educación, de valores y de metas, buscando nuevas referencias para la búsqueda del bienestar. Y cuando esto ocurra, ello no supondrá la renuncia al bienestar material, sino la apertura a esferas sociales en las que nuevas estructuras de sentido nos abran a una pluralidad de valores que no sitúen el goce del consumo como el único camino del bienestar. «Llegará el día en que la búsqueda de la felicidad en el consumo no tendrá ya el mismo poder de atracción, la misma positividad: la búsqueda de la autorrealización acabará por desviarse del camino sin fin de los placeres del consumo ${ }^{37}$. Ese momento estará más cerca a medida que entendamos que la conquista de la felicidad tiene menos que ver con la satisfacción del placer inmediato que con el resurgimiento de una verdadera ética de las virtudes ciudadanas.

35 Cf. Nussbaum, M. Women and Human Development, Cambridge, Cambridge University, 2000, pp. 70-101.

36 Para Lipovetsky las satisfacciones materiales se imponen sobre las infelicidades que puedan provocar. No hay una infelicidad de la abundancia, ya que el consumo es una fuente de placer inmediata, y las insatisfacciones que produce en lo referente a lo material son superficiales, limitadas y temporales. Pero estas insatisfacciones están subiendo alarmantemente en la esfera de la intimidad de las relaciones humanas, la decepción ahí está garantizada; Cf. La sociêté du décepcion, Textuel, París, 2006, p. 33.

37 Lipovetsky, G., Le bonheur paradoxal, París, Gallimard, 2006, pp. 336-336; La felicidad paradójica, Barcelona, Anagrama, 2007, p. 353. 


\section{Bibliografía}

Brunschwig, J. (1995). Etudes sur les philosophies hellénistiques, Epicurisme, stoücisme, scepticisme, París, Presses Universitaires de France.

Díez Patricio, A. (2011). "Creencia y Delirio», Revista de la Asociación Española de Neuropsiquiatría, marzo 2011, vol. 31, pp. 71-91.

FARrington, B. (1974). La rebelión de Epicuro, Barcelona, Laia.

Featherstone, M. (1991). Cultura de consumo y postmodernismo, Buenos Aires, Amorrortu.

Fraisse, S. (1959). «Lucréce et Pascal», Esprit, 27, pp. 437-453.

García Gual, C. y Acosta, E. (1973). Epicuro. Ética. La génesis de una moral utilitaria, Barcelona, Barral Editores.

LeClerQ, J. (1976). Las grandes lineas de la filosofía moral, Madrid, Biblioteca Hispánica de Filosofía.

Lipovetsky, G. (1983). L'ère du vide, París, Gallimard.

- (1986). La era del vacio, Barcelona, Anagrama.

- (2004). Les temps hipermodernes, París, Grasset.

- (2006). Los tiempos hipermodernos, Barcelona, Anagrama.

- (2006). Le bonheur paradoxal, París, Gallimard.

- (2007). La felicidad paradójica, Barcelona, Anagrama.

- (2006). La sociêté du décepcion, París, Textuel.

- (2008). La sociedad de la decepción, Barcelona, Anagrama.

Marcuse, H. (1967). "A propósito de la crítica del hedonismo», en Cultura y Sociedad, Buenos Aires.

Mas Torres, S. (2003). Historia de la Filosofía Antigua. Grecia y el helenismo, Madrid, UNED.

Mondolfo, R. (1968). La conciencia moral de Homero a Demócrito y Epicuro, Buenos Aires, Editorial Universitaria de Buenos Aires.

Nietzsche, F. (1979). La gaya ciencia. Barcelona, Pequeña Biblioteca Calamvs scriptorivs.

Nussbaum, M. (2000). Women and development Human, Cambridge, Cambridge University Press.

Oтто, W. F., (2006). Epicuro, Madrid.

Rist, J.M. (1977). Epicurus. An Introduction, Cambridge, Cambridge University Press. 
Román, R. (1983). «El placer y la libertad en Epicuro y Lucrecio», Axerquia, Revista de Estudios Cordobeses, n. ${ }^{\circ}$ 8, pp. 45-52.

- (2002). Lucrecio: Razón filosófica contra superstición religiosa, Córdoba, UNED.

Rubio Carracedo, J. (1996). Educación Moral, postmodernidad y democracia, Madrid, ed. Trotta.

Ruíz, J.C. (2002). De Guy Debord a Gilles Lipovetsky: el tránsito de la categoría de lo social hacia la categoría de lo individual. Director: Ramón Román Alcalá. Tesis doctoral. Universidad de Córdoba, Departamento de Ciencias Sociales y Humanidades.

Scitovsky, T. (1992). The joyless economy, New York, Oxford University Press.

Touraine, A. (1998). «¿Después del postmodernismo? La modernidad», en AA.VV., $Y$ después del postmodernismo ¿qué?, Barcelona, Ánthropos.

Turkotт, L.M. (1997). Crítica al postmodernismo, Semanario Etcétera, México, jueves 24 de julio 1997.

Recibido: 15/10/12

Aceptado: 21/12/2012 